\title{
ÖTÉVES A BANKUNIÓ Politikai célok, közgazdasági elméletek, gyakorlati eredmények
}

Németh Krisztián ${ }^{1}$

A Bankunió, pontosabban annak első pillére, az egységes bankfelügyelet 2014 novemberében kezdte meg müködését. Tanulmányomban arra vállalkozom, hogy három szempont mentén adjak értékelést a Bankunió eddigi működéséről. Elsőként megvizsgálom azokat a gazdaságpolitikai célokat, amelyek érdekében az intézményt létrehozták. Ezt követően bemutatom azokat a közgazdasági elméleteket, amelyek megvilágítják, hogy a Bankunió milyen mechanizmusokon keresztül tudja a kitűzött célokat előmozdítani. Végül pedig - merítve a lassan ötéves müködés tapasztalataiból - esettanulmányokon keresztül mutatom be, hogy a Bankunió milyen mértékben volt képes megfelelni a vele szemben támasztott elvárásoknak. A tanulmány zárásaként összefoglalom, hogy magyar szempontból milyen érvek és ellenérvek szólnak a Bankunóval való szoros együttműködés mellett és ellen.

JEL-kódok: G21, G28

Kulcsszavak: Bankunió, bankfelügyelet, Európai Unió, szanálás

\section{A BANKUNIÓ IRÁNTI IGÉNY}

A Bankunió létrehozásának igényét a 2012. június 29-i euróövezeti csúcstalálkozó, illetve az arról kiadott Nyilatkozat fektette le (Európai Tanács, 2014). A Nyilatkozat jól tükrözi, hogy az európai jogalkotók számára 2012-ben az elsődleges problémát az európai szuverén válságok kezelése jelentette. A megoldandó cél ugyanis „a bankok és az államháztartások közötti ördögi kör megtörése”. A Nyilatkozat szerint ennek lenne eszköze a Bankunió.

Egyáltalán nem véletlen, hogy 2012-ben éppen erre az ördögi körre keresett megoldást az Európai Unió. Ekkor már túl voltunk a görög szuverén válság első hullámain és az első két mentőcsomag elfogadásán is. Fontos látni, hogy habár szuverén válságról van szó, amely definíciószerüen az államháztartás fizetőképességére vonatkozik, a görög és az európai bankrendszer is mélyen érintve volt ebben

1 Németh Krisztián a Nemzetközi Bankárképző Központ oktatója és tanácsadója. 
a szuverén válságban. A görög állam által kibocsátott állampapírok jelentős része ugyanis külföldi befektetők, elsősorban külföldi bankok tulajdonában volt. Ebből tehát már kirajzolódik az ördögi kör mechanizmusa: a bankok jellemzően eszközeik jelentős hányadát tartják hazai vagy külföldi állampapírokban. A szuverén szereplők fizetésképtelensége így a bankrendszer számára is jelentős veszteséget eredményezhet. Amennyiben ezek a veszteségek egyes bankok inszolvenciájához vezetnek, akkor ismét a szuverén fél kerül döntési helyzetbe: feltőkésíti-e az adott bankot, vagy hagyja csődbe menni? Utóbbival kockáztatja, hogy a válság továbbterjed a bankrendszer többi intézményére is. A feltőkésítés esetén viszont számolni kell ennek fiskális terheivel, ami növeli az államháztartás eladósodottságát és ezen keresztül egy szuverén válság bekövetkezésének valószínüségét. Itt pedig a kör bezárul: a szuverén válság előidézhet bankválságot, ami pedig súlyosbíthatja a szuverén válságot.

Az Európai Unión belül az államháztartások és a bankrendszer közötti kedvezőtlen folyamatok megelőzésén túl egy komplex bankunió számos egyéb célt is szolgál, így például:

- A nemzetközivé vált bankok/bankcsoportok hatékonyabb felügyeletét és szabályozását teszi lehetővé, ha a szabályozás és a felügyelet is kilép a nemzeti keretek közül. Ennek egyik magyarázata a felügyeleti információk hatékonyabb áramlása (Darvas-Wolff, 2013).

- Konzisztenciát teremt a felügyeleti módszerekben.

- Az egységes piac, így az egységes pénzpiac megköveteli, hogy a felügyelet is integrált legyen. Ellenkező esetben a felügyeleti különbségek torzítani fogják a piaci szereplők döntéseit.

- Bizonyos elméletek (pl. forgóajtó-elmélet) azt támasztják alá, hogy nemzetközi szinten hatékonyabb felügyelet valósulhat meg, mint nemzeti vagy még inkább kisállami szinten.

- A monetáris unión belül az Európai Központi Bank (EKB) látja el a végső hitelezői funkciót. A válság során addicionális kockázatot jelentett az EKB-nak, amikor úgy kellett likviditást biztosítania az eurózóna bankjainak, hogy nem rendelkezett felügyeleti kontrollal felettük (Hüttle-Schoenmaker, 2016).

\section{A BANKUNIÓ PILLÉREI - A SZÁNDÉK MEGVALÓSULÁSA}

A bankuniós tagság minden euróövezeti tagállam számára kötelező. A monetáris unión kívüli EU-s tagállamoknak viszont választási lehetőségük van (opt in/opt out), hogy részt kívánnak-e venni benne.

A Bankunió $3+1$ pillérből épül fel: 


\subsection{Egységes felügyeleti mechanizmus (Single Supervisory Mechanism - SSM)}

Az SSM 2014 novemberében kezdte meg müködését. A szupranacionális felügyeleti jogkört az Európai Központi Bank (EKB) kapta meg, amely így a nemzeti hatóságokkal együttműködve látja el a prudenciális felügyeletet a Bankunióban, amelynek összesen körülbelül 6000 intézmény felügyeletét kell ellátnia (Kisgergely-Szombati, 2014). Ezek közül a jelentősnek minősített intézményeket az EKB közvetlenül felügyeli. Jelenleg az EKB hivatalos honlapja² alapján 117 ilyen jelentős intézmény müködik, amelyek az euróövezeti bankok eszközállományának megközelítőleg 82 százalékát fedik le. Minden egyes jelentősnek minősített intézmény felügyeletét egy-egy közös felügyeleti csoport (joint supervisory team) látja el. A közös felügyeleti csoport biztosítja azt a fórumot, amely a leginkább megtestesíti a nemzeti felügyeletek és az EKB közötti kooperációt. Tagjai ugyanis vegyesen kerülnek ki az EKB és azon tagállamok felügyeleti szerveinek munkatársai közül, amelyekben érdemi tevékenységet folytat a felügyelt intézmény.

A jelentősnek nem minősülő bankok felügyeletét az EKB közvetett módon, a nemzeti felügyeleti hatóságokon keresztül látja el.

\subsection{Egységes szanálási mechanizmus (Single Resolution Mechanism - SRM)}

A Bankunió második pillérének tekintett egységes szanálási mechanizmus hatáskörébe az SSM által felügyelt intézmények tartoznak. Az SRM alapvető célkitűzése, hogy egy adott intézmény csőd- vagy csődközeli helyzete és annak a kezelése a lehető legkisebb mértékben terhelje az adófizetőket. Az egységes szanálási mechanizmus két további intézményből tevődik össze ${ }^{4}$ :

- Az Egységes Szanálási Testület (Single Resolution Board - SRB) a Bankunió központi szanálási döntési testülete, amely a nemzeti szanálási hatóságokkal együttesen alkotja az SRM-rendszert. A független európai uniós ügynökség, az Egységes Szanálási Alap kezelője.

- Az Egységes Szanálási Alap (Single Resolution Fund - SRF) az SRB által kezelt pénzalap, amely a szanálási eljárás során használható fel. Létrehozását és elvárt nagyságát a 806/2014/EU rendelet rögzíti: az Alap felállítását követő első

2 https://www.bankingsupervision.europa.eu/about/thessm/html/index.hu.html

3 https://www.bankingsupervision.europa.eu/banking/approach/jst/html/index.en.html

4 https://ec.europa.eu/info/business-economy-euro/banking-and-finance/banking-union/singleresolution-mechanism_en 
nyolc évben az Alapban akkora összeget kell felhalmozni, amely lefedi az intézmények betétállományának 1 százalékát.

\subsection{Egységes Szabálykönyv (Single Rulebook)}

Az Egységes Szabálykönyv a Bankunió szellemiségének és működésének alapja, ugyanakkor eltér a többi pillértől abban, hogy nemcsak a Bankunióban, hanem az Európai Unió minden tagállamában kötelező érvényű. Az európai szinten egységes szabályozás fontos lépés a pénzügyi piacok valódi egységességének megteremtésében: hatékony eszköz a fragmentált szabályozás verseny- és allokációtorzító hatása, illetve a szabályozói arbitrázs ellen.

\subsection{Egységes betétbiztosítási rendszer (European Deposit Insurance Scheme - EDIS)}

Az egységes betétbiztosítási rendszer jelenleg még nem aktív pillére a Bankuniónak. Kialakítása körül jelenleg vita zajlik. Az Európai Bizottság 2015 novemberében tett javaslatot az egységes betétbiztosítás megvalósítására (Európai Bizottság, 2015).

A nemzeti szinten müködő betétbiztosítás hasonló problémákat vet fel, mint a nemzeti szintű szanálás: egy-egy lokális léptékben mérve nagyobb intézmény csődje jelentős terhet ró mind a nemzeti szanálási, mind a betétbiztosítási alapra. Amennyiben pedig kétség merül föl abban, hogy ez utóbbi két intézmény bármely, akár a legnagyobb helyi bank csődje esetén is el tudja-e végezni a feladatát, az a pénzügyi rendszer egészével szemben táplálja a bizalmatlanságot.

\section{A HATÁSMECHANIZMUS: HOGYAN SZOLGÁLJA A BANKUNIÓ A KIJELÖLT CÉLOKAT?}

\subsection{Az ördögi kör megtörése az államháztartás és a bankrendszer között}

Az ördögi kör korábban ismertetett, egyszerü hatásmechanizmusán túl Gerlach et al. (2010) további szempontra hívja fel a figyelmet: az államháztartásnak nem csak abban a szélsőséges esetben jelenthet többletköltséget a bankrendszer, amikor már feltőkésítésre van szükség. A piacok ugyanis már eleve beárazzák az állampapír-hozamokba egy esetleges bankmentés költségeit. Gerlach et al. (2010) fö következtetése, hogy az állampapírhozam-szpred sokkal erőteljesebben reagál az aggregált kockázatok növekedésére azokban az országokban, ahol

- jelentős a bankrendszer mérete, és

- nagy tőkeáttétellel működik a bankrendszer. 
A fenti két szempont éppen a bankmentés várható költségének két komponensével van összefüggésben: mekkora egy esetleges bankmentés költsége, és milyen valószínűséggel alakul ki bankválság?

A Bankunió szanálási mechanizmusa az első pontra ad választ: uniós szintre emeli a bankmentést. Ezáltal csökkenti a méretükhöz képest jelentős bankrendszerrel rendelkező tagállamokra nehezedő fiskális terhet, amelyet egy potenciális bankválság hordoz magában.

\subsection{A monetáris politika funkcióinak előmozdítása}

A bankrendszerek országonkénti különbözősége a 3.1. fejezet alapján erősíti a divergáló hozamgörbék jelenségét a monetáris unión belül. A monetáris unióban ugyanakkor egyetlen alapkamat létezik, amellyel praktikusan egyetlen hozamgörbét lehet hatékonyan befolyásolni, annak is elsősorban a rövid végét.

A divergáló hozamokra a legkézenfekvőbb válasz a szorosabb gazdasági integráció. A Bankunió éppen ezt a szorosabb integrációt hivatott előmozdítani a közös bankfelügyelet és válságkezelés életre hívásával. Az egységesen szigorú szabályozástól, a független, szakmai alapon müködő felügyelettől és az európai szintre emelt bankszanálástól reális elvárás lehet, hogy egyrészt mérsékli a bankrendszerek közötti különbségeket, másrészt pedig - ha a különbségeket nem is képes teljesen eliminálni -, az eltérő kockázatok kisebb mértékben csapódnak le a szuverén adósságok finanszírozási költségében. Mindezt figyelembe véve tehát a Bankunió közvetett célja lehet a közös monetáris politika hatékonyságának előmozdítása is (Kisgergely-Szombati, 2014).

\subsection{Jobb minőségü felügyelet}

Darvas-Wolff (2013) az SSM egyik előnyének tekinti a felügyeleti információk akadálytalan áramlását. Ez a tényező különösen a nemzetközi szinten működő bankok felügyeletét teszi hatékonyabbá. A Bankunió hiányában az ugyanazon bankcsoporthoz tartozó, de különböző országokban müködő leánybankok eltérő nemzeti felügyeletek alá esnének. Az adott nemzeti felügyeletnek oly módon kéne döntéseit meghoznia, hogy nem feltétlen rendelkezik átfogó képpel a bankcsoport egészének müködéséről.

A szerzőpáros továbbá azt is kiemeli, hogy egy nemzetközivé vált bankrendszer esetén, amelyet különálló nemzeti hatóságok felügyelnek, illetve adott esetben szanálnak, szükségszerűen fennáll egyfajta koordinációs probléma. A koordinációs probléma abban áll, hogy amikor egy nemzeti hatóság mérlegeli egyegy felügyeleti intézkedés (pl. bankmentés) költségét és hozadékát, akkor a ha- 
szonból kizárólag a belföldön érvényesülő hatásokat veszi figyelembe, vagyis eltekint az intézkedés olyan externális hatásaitól, amelyek egyéb országokban érvényesülnek. Ennek az az eredménye, hogy uniós szinten a felügyeleti intézkedés szuboptimális szintje valósul meg. Ebben a megközelítésben a Bankunió megvalósítása nem más, mint a felügyeleti/szanálási intézkedések költségeinek és hasznainak uniós szintű internalizálása, amely elősegíti, hogy összuniós szinten optimális felügyeleti döntések szülessenek.

\subsection{Felügyeleti szigor és engedékenység a lokalitás különböző szintjein}

Agarwal et al. (2012) tanulmánya regressziós módszertannal bizonyítja, hogy az Amerikai Egyesült Államokban a szövetségi felügyeleti szervek jellemzően szigorúbb módon járnak el a tagállami felügyeleteknél. Ebből az a következtetés is levonható, hogy minél magasabb szinten valósul meg a bankfelügyelés, annál kevésbé hajlamos az engedékeny, adott esetben túlzottan elnéző felügyelésre. Másképp fogalmazva, a felügyeleti hatóságok müködésének lokális jellege engedékenységre hajlamosít.

A jelenség elméleti magyarázatát adhatja többek között az ún. zsákmányelmélet (capture theory). Zsákmányelméletről beszélünk akkor, amikor a szabályozás vagy a felügyelés célja elsősorban nem a piaci tökéletlenségek javítása, hanem az inkumbens vállalatok zavartalan müködésének biztosítása (Viscusi-VernonHarrington, 200o). Feltételezésem szerint a felügyelet bankuniós szintre emelése mérsékli a felügyelt intézmények azon képességét, hogy kontrollálják (zsákmányul ejtsék) a hatóságot. Egy tagállami szinten jelentős bank vélhetően nagyobb lobbierőt tud kifejteni saját nemzeti hatóságára, mint az EKB-ra. Így a Bankunió hatékonyan mérsékli a felügyelet fogva tartásának lehetőségét.

A forgóajtó-elmélet (revolving door) szintén azt támasztja alá, hogy a felügyelés lokalitásának szintje befolyásolhatja a felügyelés szigorát. Forgóajtó-jelenségről beszélünk akkor, ha szabályozói, felügyeleti vagy egyéb állami szférában dolgozó személyek - kihasználva a pozíciójuk által összegyüjtött tapasztalatot és a kiépített kapcsolati hálót - a magánszférában helyezkednek el. A bankfelügyelés szempontjából a jelenség akkor különösen káros, ha az adott személy már a felügyeleti munkája során úgy látja el hivatalát, hogy azzal kiérdemeljen egy későbbi jól fizető állást valamely felügyelt intézménynél. Könnyen belátható, hogy a forgóajtójelenség ezáltal lazíthatja a felügyelet szigorát és minőségét. Ha elfogadjuk azt a hipotézist, hogy az összefonódás könnyebben alakul ki akkor, ha mind a bank, mind a felügyelet nemzeti szinten működik, akkor a Bankunió-szintü felügyelet némileg mérsékelheti ezt a forgóajtó-jelenséget. 


\subsection{A pénzügyi trilemma és a Bankunió}

Schoenmaker (2011) egy lehetetlenségi hármasra hívja fel a figyelmet. Cikkében egy játékelméleti modell keretében mutatja be azt a három gazdaságpolitikai célt, amely meglátása szerint nem érhető el egyidejüleg:

- pénzügyi stabilitás,

- nemzetközivé vált bankrendszer,

- nemzeti pénzügyi, felügyeleti politika.

Ebben a megközelítésben a Bankunió nem más, mint egy válasz a pénzügyi trilemmára. A Bankunió azt a választ hordozza, hogy az európai értékekkel összhangban az egységes piacról és ezáltal a nemzetközivé vált bankrendszerről nem lehet lemondani. Értelemszerüen a pénzügyi stabilitás is megtartandó, így szükségszerüen a nemzeti szintü felügyeleti politikáról kell lemondani.

\subsection{Felügyeleti reputáció}

Az EKB irányításával megvalósuló Egységes Felügyeleti Mechanizmusban önmagában is értéket képvisel a felügyelet reputációja. Még Kisgergely-Szombati (2014) tanulmánya is - amelyet az MNB adott ki - elismeri, hogy az EKB reputációban meghaladja a Magyar Nemzeti Bankot. Amennyiben a reputációs többlet valóban fennáll, az növeli a felügyelt intézményekkel szemben is a bizalmat, ami pedig mérsékli azok finanszírozási költségeit.

A reputáció szerepét illetően érdemes megvizsgálni Mérő-Piroska (2017) azon kérdésfeltevését, hogy a kelet-közép-európai régióban miért éppen Bulgária és Románia fejezte ki csatlakozási szándékát a Bankunióhoz. Ezzel párhuzamosan miért maradt Csehország, Lengyelország és Magyarország tartózkodó? Magyarázatként ajánlja a szerzőpáros: az egyes államoknak azon képességét hasonlítsuk össze, hogy milyen mértékben képesek saját pénzügyi rendszerük stabilitását fenntartani. Ezen képesség terén elemzésük alapján Bulgária és Románia egyértelmủen rosszabbul teljesített a másik három országnál. Így Románia és Bulgária számára jelentheti a legnagyobb hozzáadott értéket a bankuniós felügyelet hitelességének importja.

\subsection{A Bankunió szerepe a szabályozói/felügyeleti arbitrázs kezelésében}

Szabályozói vagy felügyeleti arbitrázsról beszélünk a bankszektorban akkor, ha egy bankon vagy bankcsoporton belül csak azért mozgatják az egyes tevékenységeket, hogy ezáltal azok lazább vagy más típusú szabályozás/felügyelet alá ke- 
rüljenek. Erre elsődlegesen a nemzetközi szinten müködő bankoknak van lehetőségük, amelyek kihasználják az egyes országok közötti felügyeleti és szabályozói fragmentáltságot. A jelenség szabályozói szempontból egyértelműen káros: a bankok ugyanis oly módon tudják felügyeleti/szabályozói terheiket csökkenteni, hogy a kockázataik semmilyen mértékben nem csökkenek. A jelenség azonban nem csak amiatt káros, mert egyes egyedi intézmények kockázatai megfelelő felügyelet nélkül maradhatnak. Legalább ilyen súlyos probléma, hogy a bankok menekülése a lazább felügyelet irányába a hatóságok viselkedésére is visszahat. A különböző országok felügyeletei között ugyanis verseny alakulhat ki (race to the bottom), amelynek tárgya a felügyelet lazítása (Nouy, 2017).

Milyen módon tudnak a bankok a gyakorlatban élni a felügyeleti arbitrázs lehetőségével? Elsősorban úgy, hogy rugalmasan alakítják szervezeti felépítésüket, igazodva a szabályozói környezethez. A nemzetközi bankok szervezeti felépítésének fö kérdése, hogy adott országban a szolgáltatásaikat leánybank vagy fiókbank formájában nyújtják-e. A leánybank (subsidiary) önálló jogi személynek számít, felügyeletét azon ország hatósága látja el, ahol müködik. A fiókbank (branch) ezzel szemben az anyavállalat része, így nem önálló jogi személy. Nemzetközi viszonylatban a határon átnyúló szolgáltatás megvalósításának eszköze. Mivel jogilag az anyavállalat része, így felügyeletét az anyavállalat illetékessége szerinti hatóság látja el.

\section{ESETTANULMÁNYOK A BANKUNIÓ MÜKÖDÉSÉRÖL}

\subsection{Nordea}

A Nordea bank (Nordea Bank Abp.) a skandináv régió legnagyobb bankja. 2017ben még rajta volt a G-SIB listán, azaz úgy tartották számon, mint globálisan is meghatározó méretű bankot - ennek megfelelően szigorúbb szabályozói elvárásoknak kellett megfelelnie. 2017 decemberében 581 milliárd eurós mérlegfööszszeggel rendelkezett.

2017. szeptember 6-án a Nordea igazgatótanácsa kezdeményezte az anyavállalat székhelyváltását Stockholmból (Svédország) Helsinkibe (Finnország). Bankuniós szempontból a székhelyváltás azért bír jelentőséggel, mivel Svédország nem tagja a Bankuniónak. Sőt Svédország azt is jelezte, hogy a jövőben sem kíván csatlakozni a rendszerhez. Ezzel szemben Finnország az eurózóna tagjaként automatikusan részt vesz a Bankunióban is. Így tehát a székhelyváltás egyben azt is jelenti, hogy a Nordea felügyeleti hatóságot is vált: a svéd Finansinspektionen helyett a Bankunió felügyelete alá kerül, amely a bank méretéből adódóan közvetlen EKBfelügyeletet jelent. 
2018 márciusában a Nordea közleményt adott ki , amelyben összefoglalja érveit a székhelyváltás mellett:

- A Nordea egy nemzetközi bank, amelynek mérlegföösszege bármelyik skandináv ország GDP-jének eléri a kétszeresét. A Nordea célja, hogy méretéhez igazodva kellően erős intézmény lássa el a felügyeletét. A felmerült lehetőségek közül egyértelmüen az EKB-t tartja a legerősebb felügyeletnek.

- A négy potenciális székhely közül egyedül Finnország tagja a Bankuniónak.

- A Finnországba és így a Bankunióba való áttelepülés megteremti annak lehetőségét, hogy a Nordea azonos felügyeleti környezetbe kerüljön legnagyobb európai versenytársaival. Így a köztük lévő versenyt nem torzítják felügyeleti különbségek. Ennek hatására kiszámíthatóbbá válik a bank müködési környezete.

Természetesen a székhelyváltás mögött meghúzódhatnak olyan érvek is, amelyeket a Nordea nem említ a hivatkozott közleményében. Mindenképp ki kell emelnünk a svéd stabilitási alap körüli vitát: a svéd kormány megemelte a hitelintézetek hozzájárulását az alaphoz, amely jelentős terhet jelentett volna a Nordeának. A Nordea válaszként székhelyváltással fenyegette meg a svéd kormányzatot. Az igazgatótanács 2017. szeptember 6-án valóban kezdeményezte a székhelyváltást, ami 2018. október 1-jén hivatalosan is megtörtént. Az új székhely Helsinki lett. ${ }^{6}$ A Nordea saját becslése szerint a székhelyváltással 1,1-1,3 milliárd eurót tud jelenértékben megtakarítani. A megtakarítás részben valóban annak az eredménye, hogy a bank elkerüli az emelt összegü befizetést a svéd stabilitási alapba.

Látható, hogy a székhelyváltás mögötti motiváció fontos összetevői a felügyeleti és szabályozói szigorban mutatkozó különbségek. A finn/bankuniós szabályozás mind a szanálási alap, mind a betétbiztosítás és az adózás terén lazább követelményeket támaszt a bankokkal szemben, mint Svédország. Így tehát a Nordea döntése mögött is felmerül a szabályozói arbitrázs lehetősége, annak ellenére, hogy abban egyéb bankunió-specifikus szempontok is szerepet játszhatnak: a jelentős szanálási alap vagy az európai versenytársakéval azonos szabályozói környezet.

A sajtóban megjelent cikkek leggyakrabban a svéd szanálási díjak megemelésében látják a székhelyváltás közvetlen előzményét. Véleményem szerint a döntés azonban már korábban, a kormányzati bejelentést megelőzően megszülethetett. Ezt a

5 https://www.nordea.com/en/press-and-news/news-and-press-releases/news-group/2018/whywe-propose-to-move-into-the-banking-union.html

6 https://www.nordea.com/en/press-and-news/news-and-press-releases/press-releases/2018/10o1-o7h3o-nordeas-re-domiciliation-is-completed.html

7 https:/www.nordea.com/Images/36-238152/Information\%2oregarding\%2othe\%2oproposed\%20 re-domiciliation\%2oto\%2oFinland.pdf 
feltételezést támasztja alá, hogy a Nordea már 2016-ban jelentős szervezeti átalakításba kezdett ${ }^{8}: 2016$ elött a stockholmi székhelyü bank leányvállalatain keresztül nyújtotta szolgáltatásait Dániában, Norvégiában és Finnországban. A 2016-os átalakítás lényege, hogy a leánybankokat fiókintézményekké alakították, amelyek már a stockholmi anyavállalat részei voltak, így felügyeletüket is a svéd hatóság látta el. Ezzel a lépéssel mintha már a későbbi székhelyváltást készítették volna elő: a fiókosítás hatására a Nordea teljes skandináv üzletága a svéd anyacégben összpontosult, és 2018-ban egyetlen székhelyváltással lehetett az egész szervezetet Finnországba, az EKB felügyelete alá helyezni.

\section{2. $A B L V$}

Az ABLV Bank (ABLV Bank, AS) Lettország harmadik legnagyobb bankja volt. Miután 2018 februárjában pénzmosással hozták összefüggésbe, a bank elvesztette az ügyfelek bizalmát, működése ellehetetlenült, és csődeljárást kezdeményezett maga ellen. Az esettanulmány abból a szempontból releváns, hogy Lettország az eurózóna és így a Bankunió tagja. Ennek megfelelően a bank szanálásáról, illetve annak szükségességéről már a bankuniós intézményrendszer, tehát az SRB hozta meg a döntést.

Az ABLV Bank eszközei alapján 2017. szeptember 30-án Lettország harmadik legnagyobb bankja volt. Az ABLV 3649 millió eurós eszközállományával kb. 13 százalékos piaci részesedést ért el Lettországban. ${ }^{9}$ Méretéből adódóan az EKB közvetlenül felügyelte. Az ABLV jelentőségét az is kifejezi, hogy egyike volt a hat „egyéb rendszerszinten jelentős intézménynek" (other systemically important institution - O-SII) a lett bankrendszerben. Sőt a lehető legmagasabb, 2 százalékos O-SII-tőkepuffert írta elö számára a felügyelet.

Annak, hogy a bank müködésével nincs minden rendben, már 2016 májusára egyértelművé kellett válnia. Ekkor ugyanis a lett felügyeleti hatóság (Financial and Capital Markets Commission - FCMC) több mint 3 millió euróra bírságolta az ABLV-t, és elmarasztalta a pénzmosás elleni tevékenységért felelős igazgatósági tagot. $^{10} \mathrm{~A}$ bank belső vizsgálatot indított, az FCMC pedig arra utasította, hogy erősítse meg belső ellenőrzését. További adminisztratív intézkedést azonban nem foganatosított.

8 https://www.nordea.com/en/press-and-news/news-and-press-releases/news-group/2018/whywe-propose-to-move-into-the-banking-union.html

9 https://www.financelatvia.eu/wp-content/uploads/2018/12/Banks-Statistics-Q3-2017.pdf

$10 \mathrm{https} / /$ www.bankingsupervision.europa.eu/press/pr/date/2018/html/ssm.pr18o224.en.html 
Az ABLV válságát az indította el, amikor 2018. február 13-án a FinCEN (Financial Crimes Enforcement Network, az USA pénzügyminisztériumának pénzügyi büncselekmények elleni osztálya) közleményt adott ki, amely szerint az ABLV Bank elsődleges szereplőként vesz részt pénzmosási tevékenységben. ${ }^{11} \mathrm{~A}$ FinCEN vádja szerint a bank vezetése, részvényesei és munkavállalói a pénzmosási tevékenységet az üzleti modell részeként intézményesítették a bankon belül. Annak érdekében, hogy a pénzmosási tevékenységet folytathassák, tudatosan gyengítették a belső kontrollokat, különösen a fiktív cégek (shell company) számláira vonatkozóan. A FinCEN szerint a bank tudatosan nem alkalmazott megfelelő minőségü kockázati kontrollokat, így KYC- (know your customer) és CDD- (customer due diligence) folyamatokat. A vádak szerint a bank a vesztegetés eszközétől sem riadt vissza annak érdekében, hogy illegális tevékenysége rejtve maradjon (FinCEN, 2018). Meg kell azonban azt is jegyeznem, hogy a FinCEN vádjait az ABLV vezérigazgatója, Ernests Bernis visszautasította. ${ }^{12}$

A FinCEN közleményét követően pánikszerü betétkivonás kezdődött. Továbbá a bank képtelen volt amerikaidollár-forrásokat bevonni, így dollárban denominált lejáró kötelezettségeinek rövid időn belül már nem tudott eleget tenni. Az EKB utasította az FCMC-t, hogy rendeljen el bankmoratóriumot, ezzel időt adva az ABLV menedzsmentjének, hogy stabilizálja a helyzetet. A stabilizálás azonban nem járt sikerrel. 2018. február 23-án az EKB döntést hozott az ABLV-ről, amelyben a bankot fizetésképtelennek, illetve valószínűleg fizetésképtelenné válónak („fail or likely to fail”) minősítette. Az indoklás szerint az ABLV-nek olyan mértékben romlott a likviditási helyzete, hogy feltehetően nem tud eleget tenni a lejáró kötelezettségeinek és a stresszhelyzet által generált, extrém forráskiáramlásnak.

Azáltal, hogy az EKB kimondta az ABLV fizetésképtelenségét, döntési helyzetbe hozta az SRB-t. A szanálási hatóságnak mérlegelnie kellett, hogy indokolt-e a bank szanálása. A szanálás három feltételéből az EKB döntése alapján az első teljesült, amely szerint az ABLV fizetésképtelen, vagy vélelmezhető, hogy fizetésképtelenné fog válni.

Az SRB megvizsgálta, hogy van-e olyan egyéb felügyeleti vagy a magánszektor által végrehajtható intézkedés, amely elkerülhetővé tenné a fizetésképtelenséget. $\mathrm{Az}$ SRB nemleges választ adott, kiemelve, hogy a bank 2017-es helyreállítási tervéből

11 „A pénzmosás olyan illegális, rendszerint a gazdasági szférában megvalósuló szolgáltatás, amely valamilyen (egy korábbi bűncselekményből származó) »piszkos« pénzt látszólag legális forrásból származó pénzzé konvertál" (GÁL, 2007).

12 http://leta.lv/eng/home/important/133EDo33-14AA-B89E-4A69-oBF8B494195A/ 
egyetlen likviditási intézkedés sem hajtható végre sikerrel. Így a szanálás második feltétele is teljesült.

A szanálás harmadik feltétele, hogy a szanálást a közérdek indokolja-e. Az ABLV esetében azonban az SRB úgy határozott, hogy a szanálást nem indokolja közérdek, így arra nem került sor. Az SRB indoklása szerint a közérdek azért nem indokolja a szanálást, mivel

- az ABLV által nyújtott szolgáltatások nem kritikusak a pénzügyi rendszer szempontjából;

- az SRB szerint a bank csődje nem valószínű, hogy jelentős mértékben erodálná a pénzügyi stabilitást akár Lettországban, akár az Európai Unió bármelyik másik tagállamában;

- az ABLV-nek nem jelentős az egyéb intézményekkel való összekötöttsége, a pénzügyi rendszerbe való beágyazottsága. ${ }^{13}$

A fejlemények tükrében az ABLV részvényesei 2018. február 26-án úgy döntöttek, hogy kezdeményezik a bank felszámolását. Március 5-én benyújtották a felügyeletnek a felszámolási tervezetet. A felszámolás megindítását az FCMC június 12én jóváhagyta, amelynek értelmében a menedzsment helyét felszámolási biztosok veszik át. ${ }^{14}$

\subsubsection{Az ABLV esetének értékelése}

Danièle Nouy, az SRB Felügyeleti Tanácsának elnöke közleményében kiemelte ${ }^{15}$, hogy az SSM létrehozásakor maguk a tagállamok döntöttek úgy, hogy nemzeti hatáskörben tartják a pénzmosás elleni fellépést, így az Egységes Felügyeleti Mechanizmust nem terheli felelösség. Az ABLV esete és Danièle Nouy közleménye egy ellentmondásra hívja fel a figyelmet az SSM müködésében. Az üzletviteli kockázat definíciójába beleillik a pénzmosás is, mint nem megfelelő szolgáltatásnyújtás, amely potenciálisan veszteséget okoz a banknak. A pénzmosás üzletviteli kockázatként való definiálását erősíti meg Robert Taylor 2014. november 28-án publikált beszéde is. Robert Taylor az Egyesült Királyság pénzügyi felügyeletének (Financial Conduct Authority - FCA) egyik vezetöjeként emelte ki a pénzmosást mint az üzletviteli kockázat egyik kiemelt összetevőjét, amely a bankok iránti bizalom erodálásán keresztül tud jelentős károkat okozni az intézményeknek. ${ }^{16}$

\footnotetext{
13 https://srb.europa.eu/sites/srbsite/files/20180223-summary_decision_-_latvia.pdf

14 http://www.fktk.lv/en/media-room/press-releases/7085-fcmc-permits-ablv-bank-as-toimplement-voluntary-liquidation-plan-under-control-of-fcmc.html

15 https:/www.bankingsupervision.europa.eu/press/pr/date/2018/html/ssm.pr180222.en.html

16 https://www.fca.org.uk/news/speeches/conduct-risk-briefing
} 
Az ABLV-t közvetlenül felügyelte az EKB. Az ABLV ICAAP-folyamatát tehát az EKB-nak kellett felülvizsgálnia a SREP-folyamat keretében. Mivel az ICAAP teljeskörü, így szükségszerűen tartalmaznia kellett volna a müködési kockázat egyik fontos összetevőjét, az üzletviteli kockázatot. Az üzletviteli kockázat valóságos létezésére külön felhívta a figyelmet az, hogy az FCMC 2016-ban már bírságolta pénzmosás miatt az ABLV-t. Így tehát ha Danièle Nouy közleményéből indulunk ki, amely szerint az EKB nem vizsgálhatja a pénzmosás tényállását, akkor általában véve a SREP-folyamatban sem tud teljes értékü felügyeletként részt venni, hiszen a pénzmosásnak adott esetben meg kell jelennie az ICAAP kockázati leltárában. Így pedig a felügyeletnek is szükségszerüen értékelnie kell azt.

Az SRB vélhetően rendkívül nehéz helyzetben volt, amikor az ABLV szanálásáról döntenie kellett. Az SRB korábban hivatkozott közleménye szerint azért nem állt fenn a közérdek, mivel az ABLV csődje feltételezhetően nem erodálja érdemben a pénzügyi stabilitást, és egyéb intézményekkel való összekötöttsége, pénzügyi beágyazottsága sem kellően jelentős. Ez a megállapítás viszont több ténnyel is szembemegy, amelyet az esettanulmány során ismertettem:

- Az ABLV Lettország harmadik legnagyobb bankja volt.

- Az ABLV-t O-SII-intézménynek minősítette a felügyelet, sőt a maximálisan kivethető 2 százalékos O-SII-tőkepuffert írta elő számára.

Az SRB döntésével tehát felvállalta azt a kockázatot, hogy a Bankunió működése inkonzisztensnek tünhet: egy korábban jelentősnek minősített bankot azért nem ment meg, mert mégsem találja elég jelentősnek ahhoz, hogy a pénzügyi stabilitást veszélyeztesse. Ez pedig alapot adhat az olyan kritikáknak, amelyek szerint egy kis ország nagy bankja Frankfurtból nem elég jelentős ahhoz, hogy szükség esetén felhasználják a szanálási alapot. Így tehát a kis országok hátrányban vannak a Bankunión belül. Az ABLV szanálásával viszont feltételezésem szerint még erősebb kritikát kapott volna az SRB. Akkor ugyanis rendkívül visszás lett volna, hogy a közös szanálási alapot egy pénzmosásba keveredett bank és bizonytalan hátterü ügyfeleinek a megmentésére használják fel. Így az SRB-nek végső soron azt is mérlegelnie kellett, hogy a két rossz lehetőség közül melyik a kevésbé káros a Bankunió reputációját illetően. 


\section{BANKUNIÓ MAGYARORSZÁGON: ÉRVEK ÉS ELLENÉRVEK}

Jelen fejezetben a magyar pénzügyi rendszer szempontjából vizsgálom meg a Bankuniót. Az értékelés során intenzíven támaszkodom a korábbi fejezetekre, így a tanulmány ezen szakasza összegzésnek is tekinthetö.

Mivel Magyarország nem tagja a monetáris uniónak, ezért választhat, hogy részese kíván-e lenni a Bankuniónak vagy sem. A monetáris unión kívüli tagok az ún. szoros együttmüködés keretében csatlakozhatnak a Bankunióhoz. ${ }^{17}$ Meg kell azonban jegyezni, hogy egyelőre egyetlen ország sem alakított ki szoros együttmüködési megállapodást, noha Románia, Bulgária és Dánia kifejezte csatlakozási szándékát vagy legalább érdeklődését a Bankunió iránt. Magyarország jelenleg a kivárás stratégiáját követi.

\section{1. Érvek a magyar csatlakozás mellett}

Kisgergely-Szombati (2014) a Bankunió melletti legfontosabb érvnek az EKB reputációját tekinti. A szerzőpáros kiemeli, hogy az EKB és azon keresztül az SSM felülmúlja a nemzeti felügyeletek, így az MNB szakmai reputációját. Egy esetleges csatlakozás növelné a befektetők, különösen a külföldi befektetők szemében a hazai felügyelet hitelességét. Hitelesebb felügyelet mellett a bankokat finanszírozó gazdasági szereplők - alacsonyabb kockázatokat érzékelve - kisebb hozamot várnak el befektetésüktől, ezzel mérsékelve a bankrendszer finanszírozási költségeit. Továbbá Kisgergely-Szombati (2014) kitér arra is, hogy az EKB mint felügyeleti szerv különféle befolyásoktól mentesen tudna a hazai bankrendszerre tekinteni, ami szintén a hitelességet erösítené. Megállapításuk összhangban van a 3.4. fejezetben bemutatott zsákmányelmélettel és forgóajtó-elmélettel.

A Bankunió mellett érvelhetünk a hazai bankrendszer tulajdonosi szerkezetével is. Mind Magyarországon, mind a régiós országokban magasnak tekinthető a külföldi részarány (Mérő-Piroska, 2017). Bár a pénzügyi válságot követően csökkent a külföldi tulajdon aránya Magyarországon, 2018 végén 50,1 százalék volt. ${ }^{18}$ A külföldi bankok többnyire leánybanki formában müködnek, felügyeletüket ezért jelenleg az MNB látja el. A bankuniós csatlakozással a külföldi nagybankok leánybankjai az EKB közvetlen, csoportszintű felügyelete alá kerülnének. A csoportszintü felügyelet keretében a 3. fejezetben kifejtettekkel összhangban hatékonyabb a felügyeleti információ áramlása, mintha a csoport tagjait eltérő hatóságok

17 https://www.consilium.europa.eu/hu/policies/banking-union/

18 https://www.mnb.hu/felugyelet/idosorok/i-penz-es-hitelpiaci-szervezetek/hitelintezetek 
felügyelnék. A külföldi érdekeltségü leánybankok szempontjából az is előnyös lenne, hogy a csatlakozással megszünne a kettős felügyeleti elvárásoknak való megfelelés többletterhe. Jelenleg ugyanis a csoportszintű felügyelet miatt az EKB-s, a hazai felügyelet miatt pedig az MNB-s elvárásoknak is meg kell felelniük.

A bankuniós csatlakozás további előnye a jelentős méretű szanálási alaphoz való hozzáférés. Az SRF 55 milliárd eurós célszintje impozáns: meghaladja a legnagyobb hazai bank (OTP) teljes mérlegföösszegét, saját tőkéjének pedig kb. 10-szerese. Ezzel szemben a hazai szanálási alap 90 milliárd forintos célszintje elenyésző: az OTP mérlegfőösszegének alig fél százaléka, saját tőkéjének nem egészen 5 százaléka. ${ }^{19}$ Az OTP mérleg- és eredményadataival való összehasonlítás azt hivatott kifejezni, hogy a hazai szanálási alap elsősorban a kisebb intézmények megmentésére lehet elegendő. A nagyobb hazai intézmények számára azonban érdemi hozzáadott értéke lenne az európai szintű szanálási alaphoz való hozzáférésnek.

A csatlakozás mellett szól az is, hogy a döntés nem végleges és visszafordíthatatlan. A szoros együttműködésben lévő tagállamoknak lehetőségük van az azonnali kilépésre, amennyiben

- nem értenek egyet a Felügyeleti Tanács valamely előterjesztésével - erről tájékoztatják a Kormányzótanácsot, de ez utóbbi mégis elfogadja az előterjesztést;

- a Felügyeleti Tanács valamely előterjesztését a Kormányzótanács elutasította. Az elutasító döntéssel nem értenek egyet, erről tájékoztatják a Kormányzótanácsot, de az nem hajlandó korábbi elutasító döntésén változtatni (KisgergelySzombati, 2014).

\section{2. Érvek a magyar csatlakozás ellen}

Az előző alfejezetben bemutatott érvek más megvilágításba is helyezhetők. Jogos feltételezés, hogy a hazai bankok lobbiereje és „fogvatartási” képessége elenyésző lenne az európai szintű bankfelügyeletre. Ez azonban nem jelenti azt, hogy európai szintű bankcsoportok ne tudnának nyomást gyakorolni a felügyeletre. Így fennáll a veszély: a bankuniós csatlakozással csak annyi változna, hogy a hazai intézmények helyett azok nemzetközi versenytársai tudnák jobban érvényesíteni az érdekeiket.

19 https://www.otpbank.hu/portal/hu/IR_Kiemelt_adatok 
A bankuniós szanálási döntéseket illetően intő jel lehet Andrea Enria megálla-

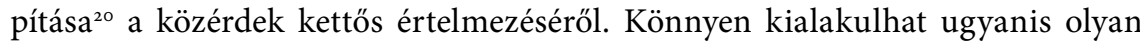
helyzet, amelyben a közérdeknek eltérő értelmezése alakul ki európai (SRB) és tagállami szinten. Erre mutatott rá két olasz bank, a Banca Popolare di Vicenza és a Veneto Banca fizetésképtelensége 2017 nyarán: az SRB megállapította, hogy a bajba jutott bankok szanálását nem indokolja közérdek. Ezzel szemben viszont az olasz állam kvázi szanálást hajtott végre, jelentős mennyiségű kormányzati forrást felhasználva. Ez pedig kétségeket ébreszt afelől, hogy a Bankunió eredményesen mozdítja-e elő a kitűzött célt: a bankok és az állam közötti ördögi kör megtörését. Magyar szemmel különösen megfontolandó a lett ABLV esete. Annak ellenére, hogy a bank 13 százalékos piaci részesedéssel rendelkezett a lett bankpiacon, továbbá O-SII-intézményként tartották számon, mégsem került sor a szanálására. Az indoklás a közérdek hiánya volt. Ez magyar szemmel alapot adhat egy lényeges ellenérvnek a Bankunióval szemben: az európai döntéshozók számára a hazai bankok nem elég jelentősek ahhoz, hogy szükség esetén itt használják fel a szanálási alapot. Ne felejtsük el, hogy Magyarországon az MKB esetében az MNB a szanálás mellett döntött 2014 végén. Bár az MKB mérlegföösszege közel kétszerese volt az ABLV mérlegföösszegének, piaci részesedése azonban csak 7 százalék körül alakult.

A szanálási alap 55 milliárd eurós célszintje valóban impozáns. Kisgergely-Szombati (2014) azonban felveti, hogy bankuniós döntési mechanizmus tud-e olyan gyors lenni, mint a hazai megfelelöje. A jelenlegi hazai modellben ugyanis a szanálási forgatókönyvet egyedül a Pénzügyi Stabilitási Tanácsnak kell jóváhagynia, majd a jóváhagyás után azonnal kezdődhet a megvalósítás. A bankuniós mechanizmus azonban többszereplös döntést igényel, ami lassítja a folyamatot. Szanálási döntéseknél viszont a gyorsaság a hatékony intézkedés alapja és feltétele.

További lényeges szempont, hogy a Bankunióhoz való csatlakozás Magyarország számára éppen azt jelentené, hogy megbomlana a monetáris politika és a felügyelet intézményi egysége. Ez pedig valószínűleg lassítaná a felügyeleti és monetáris politikai funkciók közötti információáramlást. A monetáris politikának viszont egy bankválság során kiemelten fontos, hogy felügyeleti információhoz jusson az adott bankról, amely alapján mérlegelheti, hogy a válság likviditási vagy szolvenciális jellegü-e. Egy tisztán likviditási válság is könnyen szolvenciális vál-

20 Andrea Enria az Európai Bankhatóság elnökeként nyilatkozott a Banca Popolare di Vicenza és a Veneto Banca bankokat érintő szanálási döntésről. Az SRB elutasította a szanálást, az olasz állam ugyanakkor jelentős kormányzati támogatások biztosításával igyekezett tompítani a két olasz bank felszámolásának káros hatásait a pénzügyi stabilitásra. Enria a jelenségre mint a közérdek kettős (európai és tagállami) értelmezése hivatkozott (Európai Parlament, 2017). 
sággá fokozódhat, ha a központi bank a kritikus pillanatban a szükséges információk hiányában késlekedik.

A 4. fejezetben bemutatott esettanulmányok több helyen rámutattak arra, hogy Bankunió müködése nem teljesen kiforrott (pl. pénzmosás elleni felügyeleti felelősség kérdése). Mivel a szoros együttmüködés kezdeményezésére bármikor van lehetőség, ezért könnyen érvelhetünk amellett, hogy a kivárás racionális stratégia: akkor célszerü csatlakozni, amikor már többéves sikeres müködés bizonyítja, hogy a Bankunió elméleti előnyei a gyakorlatban is érvényesülnek. A csatlakozás időzítését illetően az is megfontolandó, hogy egyelőre egyetlen tagállam felügyelete sem lépett szoros együttműködésre az EKB-val. Különösen amiatt, mivel a régiós országok sem csatlakoztak a Bankunióhoz, a kivárás stratégiája nem eredményez érdemi versenyhátrányt Magyarország számára.

Mérő-Piroska (2017) szerint a hazai bankszektorban a külföldi tulajdon magas aránya a bankuniós csatlakozással szembeni érvként is felhozható. A szerzők a bankpolitika három fö területét nevezik meg, amelyen keresztül az állam hatni tud a bankrendszerre: tulajdonlás, szabályozás és felügyelet. Ezek közül a külföldi tulajdon magas aránya miatt a tulajdonláson keresztül a hazai szereplők csak korlátozott befolyással bírnak a magyar bankrendszerre. A szabályozás területén az Egységes Szabálykönyv Magyarországon is kötelező érvényü, így a hazai jogalkotásnak szintén erősen korlátozott a mozgástere abban, hogy befolyásolni tudja a hazai bankok müködését. Ebben a megközelítésben tehát a Bankunióhoz való csatlakozás az utolsó olyan terület feladását jelentené, amelyen keresztül az állam és az őt képviselő hatóságok befolyással bírnak a magyar bankrendszerre. Ez pedig Mérö-Piroska (2017) szerint nem lenne összeegyeztethető a magyar kormány politikai szándékaival.

\section{HIVATKOZÁSOK}

Agarwal, S. - Lucca, D. - Seru, A. - Trebbi, F. (2012): Inconsistent Regulators: Evidence From Banking. National Bureau Of Economic Research, Working Paper 17736 (https://www.nber.org/ papers/w17736.pdf, letöltve: 2019.02.10).

DARvas, Zsolt - WolfF, G. B. (2013): Should non-euro area countries join the single supervisory mechanism? Bruegel: Policy Contribution (https://doi.org/10.2478/danb-2013-0007).

Európai Bizottság (2015): Az Európai Parlament és a Tanács rendelete a 806/2014/EU rendeletnek az európai betétbiztosítási rendszer létrehozása érdekében történő módosításáról (https://eurlex.europa.eu/legal-content/HU/TXT/PDF/?uri=CELEX:52015PC0586\&from=EN, letöltve: 2019.01.21.).

Európai Parlament (2017): Briefing. The orderly liquidation of Veneto Banca and Banca Popolare di Vicenza (http://www.europarl.europa.eu/RegData/etudes/BRIE/2017/602094/IPOL_ BRI(2017)602094_EN.pdf, letöltve: 2019.03.22. 23:04). 
Európai Tanács (2014): Bankunió. Az Európai Tanács következtetései erről a témáról (https://www. consilium.europa.eu/media/21535/sno4481hu14.pdf, letöltve: 2019.01.03.).

FinCEN (2018): Proposal of Special Measure against ABLV Bank, as a Financial Institution of Primary Money Laundering Concern (https://www.fincen.gov/sites/default/files/federal_ register_notices/2018-02-13/ABLV\%2oNPRM\%2020180212\%20\%28Final\%2ofor\%2oFR\%20 Submission\%29.pdf, letöltve: 2019.03.15.).

FSB (2018): 2018 list of global systemically important banks (G-SIBs), http://www.fsb.org/wpcontent/uploads/P161118-1.pdf (letöltve: 2019.03.07.).

Gerlach, S. - Schulz, A. - Wolff, G. B. (2010): Banking and sovereign risk in the euro area. Deutsche Bundesbank, Eurosystem, Discussion Paper, Series 1, Economic Studies, No. 09/2010.

Hüttle, P. - Schoenmaker, D. (2016): Should the 'outs' join the European Banking Union? Bruegel: Policy Contribution, 2016/03.

Kisgergely KornéL - Szombati Anikó (2014): Bankunió magyar szemmel - Hogyan látja az MNB a szoros együttműködés lehetőségét? MNB-tanulmányok, 115.

Mérő Katalin - Piroska Dóra (2017): Bankunió és banknacionalizmus - A magyar eset kelet-közép-európai kontextusban. Politikatudományi Szemle, 26(1), 135-160.

Nouy, D. (2017): Gaming the rules or ruling the game? - How to deal with regulatory arbitrage (speech), (https://www.bankingsupervision.europa.eu/press/speeches/date $/ 2017 / \mathrm{html} / \mathrm{ssm}$. sp170915.en.html, letöltve: 2019.03.01.).

Schoenmaker, D. (2011): The Financial Trilemma. Economics Letters 111(1), 57-59.

Viscusi, W. K. - Vernon, J. M. - Harrington, J. E. (2000): Economics of Regulation and Antitrust. 3rd Edition, Cambridge: MIT Press.

Hivatkozott jogszabály:

Az Európai Parlament és a Tanács 806/2014/EU rendelete (https://eur-lex.europa.eu/legal-content/ HU/TXT/PDF/?uri=CELEX:32014Ro806\&from=en, letöltve: 2019.01.20.).

További online források:

Az Európai Biztosság honlapja: https://ec.europa.eu/info/index_en.

Az Európai Központi Bank honlapja: https://www.bankingsupervision.europa.eu/home/html/index.en.html.

Az Európai Unió hivatalos honlapja: https://europa.eu/european-union/index_hu.

FCA (Financial Conduct Authority) honlapja: https://www.fca.org.uk/.

FCMC (Financial and Capital Market Commission) honlapja: http://www.fktk.lv/en/.

Finance Latvia Association honlapja: https://www.financelatvia.eu/en/.

Leta (Latvian Information Agency) honlapja: http://leta.lv/eng.

MNB honlapja: https://www.mnb.hu/.

Nordea (2018): Annual Report (https://www.nordea.com/Images/33-304448/Annual\%2oReport\%20 Nordea\%2oBank\%20Abp\%202018.pdf, letöltve: 2019.03.07).

Nordea honlapja: https://www.nordea.com

Nordea press release: Why we propose to move into the Banking Union, 2018.03.08. (https://www. nordea.com/en/press-and-news/news-and-press-releases/news-group/2018/why-we-proposeto-move-into-the-banking-union.html, letöltve: 2019.03.09.).

OTP Bank honlapja: https://www.otpbank.hu/portal/hu/Maganszemelyek. 